\title{
Editor's Report for Volume 116 (2002)
}

Mailing dates for issues in volume 116 were: (1) 30 November 2002; (2) 14 March 2003; (3) 15 April 2003; (4) 16 May 2003.

A summary of membership and subscriber totals 2002 is given in Table 1. The number of articles and notes in volume 116 is summarized in Table 2 by topic; totals for Book Reviews and New Titles are given in Table 3 , and the distribution of content by page totals per issue in Table 4. Council contined making $80 \%$ of the annual interest from the Manning Fund and other capital available to The Canadian Field-Naturalist to offset the publication cost of northern papers where authors' and institutional contributions were insufficient to cover page charges.

St. Joseph Print Group set and printed the journal. Special thanks are due Emile Holst, and to Cecilia Chow and Cameron Fraser and staff for galleys and corrections. Wanda J. Cook proof-read galleys for number 1, and Elizabeth Morton for numbers 2, 3, and 4. Bill Cody as Business Manager handled all reprint requests and bills and oversaw and proofed the compilation of the Index prepared by Leslie Durocher. Wilson Eedy continued as Book-Review Editor.

Manuscripts (excluding book reviews, notices, and reports) submitted to The Canadian Field-Naturalist totalled 100 in 2002, down 15 from 2001. The following reviewed papers that had been submitted in 2002: Associate Editors: R. Anderson, Canadian Museum of Nature, Ottawa (8); C. D. Bird, Erskine, Alberta (19); R. R. Campbell, St. Albert, Ontario (3); P. M. Catling, Agriculture and Agri-food Canada, Ottawa (10); B. W. Coad, Canadian Museum of Nature, Ottawa (2); A. J. Erskine, Canadian Wildlife Service, Sackville, New
TABLE 2. Number of articles and notes published in The Canadian Field-Naturalist Volume 116 (2002) by major field of study.

\begin{tabular}{lccc}
\hline \hline Subject & Articles & Notes & Total \\
\hline Mammals* & 13 & 18 & 31 \\
Birds & 12 & 2 & 14 \\
Amphibians + reptiles & 3 & 1 & 4 \\
Fish & 6 & 3 & 9 \\
Plants & 12 & 1 & 13 \\
Tributes & 1 & 0 & 1 \\
\hline Totals & 47 & 25 & 72 \\
\hline \hline
\end{tabular}

* includes one feature article of history of Bison introductions at Wood Buffalo Park in 116(1).

TABLE 3. Number of reviews and new titles published in Book Review section of The Canadian Field-Naturalist Volume 116 by topic.

\begin{tabular}{lcc}
\hline \hline & Reviews & New Titles \\
\hline Zoology & 52 & 46 \\
Botany & 8 & 17 \\
Environment & 17 & 37 \\
Miscellaneous & 8 & 12 \\
Young Naturalists & 0 & 19 \\
\hline Totals & 85 & 131 \\
\hline \hline
\end{tabular}

Brunswick (24); D. F. McAlpine, New Brunswick Museum, Saint John (8); D. W. Nagorsen, Victoria, British Columbia (12); W. O. Pruitt, Jr., University of Manitoba, Winnipeg (22); Others: R. Aiken, Mt. Alison University, Sackville, New Brunswick; E. M. Baggs, Memorial University of Newfoundland, St. John's; J. R. Bider, Ecomuseum, Ste-Anne-

TABle 1. The 2003 circulation of The Canadian Field-Naturalist (2000 in parenthesis). Membership totals from Annual Report of the Ottawa Field-Naturalists' Club, January 2003; subscription totals compiled by W. J. Cody. Forty percent of membership dues and $100 \%$ of subscriptions go to publication of The Canadian Field-Naturalist. Members vote on Club affairs; subscribers and institutions do not.

\begin{tabular}{|c|c|c|c|c|c|c|c|}
\hline \multirow[b]{2}{*}{ Memberships } & \multicolumn{2}{|c|}{ Canada } & USA & \multicolumn{2}{|c|}{ Other } & \multicolumn{2}{|c|}{ Totals } \\
\hline & & & & & & & \\
\hline Family \& individual & 911 & $(941)$ & $32 \quad(30)$ & 8 & (7) & 951 & (978) \\
\hline \multicolumn{8}{|l|}{ Subscriptions } \\
\hline Individuals & 164 & (189) & $65 \quad(63)$ & 5 & (3) & 234 & $(255)$ \\
\hline Institutions & 171 & (174) & $252(262)$ & 32 & (38) & 455 & (474) \\
\hline Totals & 335 & (363) & 317 (325) & 37 & (41) & 689 & (729) \\
\hline TOTALS & 1246 & (1304) & $349(355)$ & 45 & $(48)$ & 1640 & (1707) \\
\hline
\end{tabular}

Note: 22 countries are included under "Other" (outside Canada and United States): Austria, Belgium, Brazil, Denmark (2), United Kingdom (9: including 1 to Scotland), Finland (2), France (3: including 1 to St. Pierre \& Miquelon), Germany (2), Iceland, Ireland, Japan, Mexico, Netherlands (3), New Zealand, Norway (4), Poland, Russia, South Africa, Spain (3), Sweden (2), Switzerland (2), Trinidad and Tobago. 
TABLE 4. Number of pages per section published in The Canadian Field-Naturalist Volume 116 (2002) by issue.

\begin{tabular}{lrrrrr}
\hline \hline & $(1)$ & $(2)$ & $(3)$ & $(4)$ & Total \\
\hline Articles & 119 & 122 & 138 & 117 & 496 \\
Notes & 21 & 21 & 0 & 11 & 53 \\
Feature & 19 & 0 & 0 & 0 & 19 \\
Tributes & 0 & 5 & 0 & 0 & 5 \\
Book Reviews* & 17 & 23 & 15 & 29 & 84 \\
News and Comment & 5 & 2 & 2 & 2 & 11 \\
CFN/OFNC Reports** & 0 & 3 & 9 & 3 & 15 \\
Index & 0 & 0 & 0 & 29 & 29 \\
Advice to & & & & & \\
Contributors & 1 & 0 & 0 & 1 & 2 \\
\hline Totals & 182 & 176 & 164 & 192 & 714 \\
\hline \hline
\end{tabular}

*Total pages for book review section include both reviews and new titles listings.

**Includes CFN Editor's reports (issue 2), OFNC Annual Business Meeting (3) and OFNC Awards (4).

de-Bellevue, Quebec; G. R. Bortolotti, University of Saskatchewan, Saskatoon; D. Boyd, Corvallis, Montana; I. Brodo, Canadian Museum of Nature, Ottawa; R. J. Brooks, University of Guelph, Ontario; C. Buddle, McGill University, Montreal, Quebec; L. Carbyn, Canadian Wildlife Service, Edmonton, Alberta (3): J. G. Casey, Narragansett, Rhode Island; J. Cayouette, Agriculture and Agri-food Canada, Ottawa; W. J. Cody, Agriculture and Agri-food Canada, Ottawa (14); K. Conlan, Canadian Museum of Nature, Ottawa; M. Costello, Huntsman Marine Science Centre, St. Andrews, New Brunswick; C. Crompton, Boularderte Centre, Nova Scotia; S. J. Darbyshire, Agriculture and Agri-Food Canada, Ottawa (2); M. Gingras, University of Alberta, Edmonton; E. Haber, National Botanical Services, Ottawa (11); S. J. Hannon, Uni- versity of Alberta, Edmonton; A. Harestad, Simon Fraser University, Burnaby, British Columbia; S. J. Hecnar, Lakehead University, Thunder Bay, Ontario; C. S. Houston, Saskatoon, Saskatchewan (2); B. Husband, University of Guelph, Ontario; L. Imbeau, Université du Québec en Abitibi-Temiscamingue, Rouyn-Noranda; R. James, Sutherland, Ontario; K. Joly, U. S. Geological Survey, Anchorage, Alaska; E. Kenchington, Fisheries and Oceans Canada, Dartmouth, Nova Scotia; T. Kinley, Sylvan Consulting Ltd, Invermere, British Columbia; C. J. Krebs, University of British Columbia, Vancouver; J. Maunder, Newfoundland Museum, St. John's; L. D. Mech, U. S. Geological Survey, St. Paul, Minnesota; J. D. Montgomery, Susquehanna SES Environmental Laboratory, Berwick, Pennsylvania; D. Otis, Clemson University, South Carolina; J. Pojar, British Columbia Ministry of Forests, Smithers; C. St. Claire, University of Alberta, Edmonton; I. Stirling, Canadian Wildlife Service, Edmonton, Alberta; K. W. Stewart, University of Manitoba, Winnipeg; J. Thomson, University of Toronto, Ontario; V. Vickery, McGill University, Montreal; M-A. Villard, Université de Moncton, New Brunswick; R. Wassersug, Dalhousie University, Halifax, Nova Scotia; M. Wheatley, Nunavut Wildlife Management Board, Iqaluit.

I am also indebted to Gary McNulty, President of the Ottawa Field-Naturalists' Club, and the Club Council for continuing support of the journal; Chairman Ron Bedford and the Publications Committee of the OFNC for editorial encouragement and support, to the Canadian Museum of Nature for access to its library and the facilities at the Natural Heritage Building, 1740 Pink Road, Aylmer, Quebec, and to Joyce for everything else.

FRANCIS R. COOK Editor 